University of Nebraska - Lincoln

DigitalCommons@University of Nebraska-Lincoln

To Improve the Academy

Professional and Organizational Development Network in Higher Education

1994

Teaching Improvement Practices: New Perspectives

W. Alan Wright

M. Carol O'Neil

Follow this and additional works at: https://digitalcommons.unl.edu/podimproveacad

Part of the Higher Education Administration Commons

Wright, W. Alan and O'Neil, M. Carol, "Teaching Improvement Practices: New Perspectives" (1994). To Improve the Academy. 327.

https://digitalcommons.unl.edu/podimproveacad/327

This Article is brought to you for free and open access by the Professional and Organizational Development Network in Higher Education at DigitalCommons@University of Nebraska - Lincoln. It has been accepted for inclusion in To Improve the Academy by an authorized administrator of DigitalCommons@University of Nebraska - Lincoln. 


\section{Teaching Improvement Practices: New Perspectives}

\section{W. Alan Wright \\ M. Carol O'Neil}

Dalhousie University

The movement to improve the quality of teaching and learning in higher education has gained increasing importance over the last several years. Policies and programs aimed at enhancing instruction are becoming commonplace as post-secondary institutions strive to provide a high quality educational experience for students. The impact of different teaching improvement practices varies, and decision-makers in universities and colleges need to know where best to place their efforts and resources. The experienced judgement of teaching improvement practitioners can assist others in making these decisions.

This study examines the results of surveys of key instructional development role players at universities and colleges in the United States and in Canada and compares the responses of the two respondent groups. Respondents rated the potential of 36 practices to improve teaching at their respective institutions. Analysis revealed patterns of agreement and disagreement within and between the U.S. and Canadian respondent groups. The leadership of deans and department heads and employment policies and practices were seen as having the greatest potential to improve teaching. Respondents had the least confidence that summative evaluation of teaching would improve instruction.

The last several years have seen a growing interest in ways to improve the quality of teaching and learning in higher education. There is a 
widespread belief that post-secondary institutions must broaden their notions of scholarship to include a greater emphasis on teaching and to take steps to improve the quality of educational processes. As a result, the teaching improvement movement has taken on increased importance in the higher education sphere in a number of countries. New and existing policies and programs designed to enhance teaching and learning are subject to increased scrutiny as instructional developers, faculty, and administrators attempt to meet the challenges of the shifting emphasis to educational goals and tangible educational outcomes.

This report describes the results of an inquiry into the perceived impact of teaching improvement practices on university and college campuses in the United States and Canada. The United States portion of the study was undertaken with the support of the Professional and Organizational Development Network in Higher Education under the 1993-94 POD Grant Program. The research has since been extended to the United Kingdom and Australia and the results of the complete international study will be included in a forthcoming volume. ${ }^{1}$

Utilizing survey research, the study recorded the perceptions of key campus players regarding the teaching improvement potential of a variety of institutional policies and practices. The analysis yielded information about patterns of agreement and disagreement within and between the U.S. and Canadian groups, providing a commentary on the various improvement initiatives. We believe that the information presented from our surveys can assist institutions and individuals in making informed decisions when planning and evaluating teaching improvement strategies.

\section{Method}

The purpose of the study was twofold: first, to examine how key instructional development role players at universities and colleges in the United States perceive the potential impact of various teaching improvement practices; second, to compare these results with data obtained from a similar group at Canadian universities.

\footnotetext{
${ }^{1}$ Wright, W. Alan. (in press). Teaching improvement practices: Successful strategies for higher education. Bolton, MA: Anker.
} 
The U.S. sample was drawn from the membership of the Professional and Organizational Development Network in Higher Education (POD). Questionnaires were sent to 290 individual members of POD from either a university or college (members from other types of institutions or organizations were not included in the sample). To ensure proper distribution among institutions, each university, college, or semi-autonomous campus received only one questionnaire. In the case of institutions with more than one POD member, an attempt was made to identify the most appropriate respondent, defined in the cover letter as "a director of a faculty development center, a head of a committee on teaching and learning, or an academic whose specific responsibility is faculty development." As a further means of ensuring that the response group contained only pertinent campus actors, the survey instrument included a question about the nature of the respondent's involvement in teaching improvement activities. The initial mailing and follow-up letters to non-respondents yielded 165 completed questionnaires, a response rate of $5 \% \%$.

The questionnaire included two sections. The first requested information on the specific role of the respondent in teaching improvement activities, the institutional structures aimed at enhancing/improving teaching, the size of the student population, and the institution's Carnegie classification (The Carnegie Foundation for the Advancement of Teaching, 1987). The second section consisted of a list of 36 items (activities, policies, and practices) related to teaching improvement. The respondent was asked to "rate each item to indicate the confidence you have in its potential to improve the quality of teaching in your university."

The aggregate responses for the 36 teaching improvement practices were then rank-ordered from highest to lowest according to the mean score of each item on the rating scale of 1 (least confident) to 10 (most confident). Ranking of individual questionnaire items in this way establishes respondents' relative confidence levels in the potential of each activity to improve teaching. This method of analysis allows for comparison between national respondent groups by taking into account their tendencies to give higher or lower overall ratings. The resulting patterns of response provide the basis for the development of a preliminary profile of assessments made by teaching im- 
provement actors in the two national settings. Although a detailed analysis and comparison of data according to the specific roles of respondents and factors like institutional size and mission would be of interest, such an analysis is beyond the scope of this article.

An analytic framework of nine previously-defined categories ${ }^{2}$ of four items each provided a means of grouping related policies and activities. These categories allowed for the identification of areas of institutional priority and responsibility for the initiation and implementation of the teaching improvement practices.

\section{Results}

The study analyzed the responses from key instructional development role players at 165 university and college campuses in the United States and 51 universities in Canada (approximately $85 \%$ of all Canadian degree-granting institutions). Table 1 provides a summary of the respondents' roles and the institutions' structures, sizes, and Carnegie classifications (except that the latter is not identified in the Canadian case).

Table 2 and Table 3 provide a rank-ordering of the responses according to the results of the U.S. survey. The Canadian results are included (but not rank-ordered) for comparison purposes. Table 2 lists the mean rating and standard deviation for each questionnaire item, from the highest rated to the lowest. Table 3 lists the nine categories employed by the researchers, rank-ordered by the aggregate mean of the four component items in each. These results are discussed in more detail below.

Table 4 outlines the various institutional structures related to teaching and teaching improvement at the universities and colleges of both Canadian and U.S. respondent groups.

\footnotetext{
${ }^{2}$ The categories and an early version of the questionnaire were devised in 1991 by Roger Barnsley of St. Thomas University, Graham Skanes of Memorial University of Newfoundland, and Alan Wright of Dalhousie University. The questionnaire was first used in June 1991 in the context of an instructional development seminar for senior university administrators in the Association of Atlantic Universities (Canada). Several surveys on instructional development practices from the United States and Canada, used prior to 1990 , were consulted when designing the questionnaire (see especially Erickson, 1986; Cochran, 1989).
} 


\section{TABLE 1 \\ Respondents' Profile}

\begin{tabular}{|c|c|c|c|c|}
\hline & $\begin{array}{r}\text { Unite } \\
\text { (165 re }\end{array}$ & $\begin{array}{l}\text { ates } \\
\text { dents) }\end{array}$ & $(51 \mathrm{re}$ & la \\
\hline $\begin{array}{l}\text { Respondent's Involvement in Teaching } \\
\text { Improvement Activities }\end{array}$ & $\mathrm{N}$ & $\%$ & $\mathrm{~N}$ & $\%$ \\
\hline $\begin{array}{l}\text { Full time director of instructional } \\
\text { development office }\end{array}$ & 42 & 25.5 & 8 & 15.7 \\
\hline $\begin{array}{l}\text { Part time director of instructional } \\
\text { development office }\end{array}$ & 30 & 18.2 & 13 & 25.4 \\
\hline $\begin{array}{l}\text { Full time faculty member \& Chair of } \\
\text { teaching committee }\end{array}$ & 28 & 17.0 & 9 & 17.6 \\
\hline $\begin{array}{l}\text { Person responsible for (among other things) } \\
\text { faculty development }\end{array}$ & 34 & 20.6 & 5 & 9.8 \\
\hline Other & 29 & 17.6 & 15 & 29.4 \\
\hline Missing & 2 & 1.2 & 1 & 2.0 \\
\hline Size of Institution (student enrollment) & $\mathrm{N}$ & $\%$ & $\mathrm{~N}$ & $\%$ \\
\hline$<1,000$ & 14 & 8.5 & 4 & 7.8 \\
\hline 1,001 to 2,500 & 30 & 18.2 & 7 & 13.7 \\
\hline 2,501 to 5,000 & 26 & 15.8 & 8 & 15.7 \\
\hline 5,001 to 10,000 & 31 & 18.8 & 9 & 17.6 \\
\hline 10,001 to 20,000 & 27 & 16.4 & 10 & 19.6 \\
\hline$<20,000$ & 32 & 19.4 & 12 & 23.5 \\
\hline Missing & 5 & 3.0 & 1 & 2.0 \\
\hline Carnegie Classification of Institution & $\mathrm{N}$ & $\%$ & $\mathrm{~N}$ & $\%$ \\
\hline Research University I & 33 & 20.0 & \multirow{11}{*}{\multicolumn{2}{|c|}{ (Not Applicable) }} \\
\hline Research University II & 12 & 7.3 & & \\
\hline Doctorate-Granting University 1 & 11 & 6.7 & & \\
\hline Doctorate-Granting University II & 4 & 2.4 & & \\
\hline Comprehensive University or College I & 36 & 21.8 & & \\
\hline Comprehensive University or College II & 16 & 9.7 & & \\
\hline Liberal Arts College I & 11 & 6.7 & & \\
\hline Liberal Arts College II & 8 & 4.8 & & \\
\hline $\begin{array}{l}\text { Two-Year Community, Junior, or Technical } \\
\text { College }\end{array}$ & 14 & 8.5 & & \\
\hline $\begin{array}{l}\text { Professional School or other Specialized } \\
\text { Institution }\end{array}$ & 15 & 9.0 & & \\
\hline Missing & 5 & 3.0 & & \\
\hline
\end{tabular}




\section{TABLE 2 \\ Items by Rank}

Rate each item to indicate the confidence you have in its potential to improve the quality of teaching in your university.

\begin{tabular}{|l|r|r|r|r|r|r|}
\hline \multirow{2}{*}{ Teaching Improvement Practice } & \multicolumn{3}{|c|}{ United States } & \multicolumn{3}{c|}{ Canada } \\
\cline { 2 - 7 } & Rank & Mean & \multicolumn{1}{c|}{ S.D. } & Rank & Mean & \multicolumn{1}{c|}{ S.D. } \\
\hline $\begin{array}{l}\text { Recognition of teaching in tenure and } \\
\text { promotion decisions }\end{array}$ & 1. & 8.30 & 1.65 & 1. & 8.68 & 1.64 \\
\hline $\begin{array}{l}\text { Deans/Heads foster importance of } \\
\text { teaching responsiblities }\end{array}$ & 2. & 8.13 & 1.66 & 4. & 7.60 & 1.94 \\
\hline $\begin{array}{l}\text { Deans/Heads promote climate of trust for } \\
\text { classroom observation }\end{array}$ & 3. & 8.00 & 1.87 & 26. & 6.43 & 2.35 \\
\hline Center to promote effective instruction & 4. & 7.72 & 1.93 & 3. & 7.70 & 1.52 \\
\hline $\begin{array}{l}\text { Deans/Heads praise \& reward good } \\
\text { teaching }\end{array}$ & 5. & 7.65 & 1.77 & $8 . *$ & 7.31 & 2.03 \\
\hline $\begin{array}{l}\text { Mentoring programs \& support for new } \\
\text { professors }\end{array}$ & $6 . *$ & 7.63 & 1.60 & 7. & 7.39 & 1.46 \\
\hline $\begin{array}{l}\text { Grants to faculty to devise new } \\
\text { approaches to teaching }\end{array}$ & $6 . *$ & 7.63 & 1.82 & 22. & 6.67 & 1.85 \\
\hline $\begin{array}{l}\text { Deans/Heads give funds/opportunity for } \\
\text { dassroom research }\end{array}$ & 8. & 7.55 & 1.90 & 6. & 7.45 & 1.79 \\
\hline $\begin{array}{l}\text { Hiring practices require demonstration of } \\
\text { teaching ability }\end{array}$ & 9. & 7.48 & 2.10 & 2. & 7.98 & 1.64 \\
\hline $\begin{array}{l}\text { Consultation on course materials with } \\
\text { faculty peers }\end{array}$ & 10. & 7.43 & 1.58 & $8 . *$ & 7.31 & 1.63 \\
\hline $\begin{array}{l}\text { Senior admin. give visibility to teaching } \\
\text { improvement activities }\end{array}$ & 11. & 7.34 & 1.86 & 10. & 7.30 & 1.84 \\
\hline $\begin{array}{l}\text { Videotaping classroom teaching for } \\
\text { analysis \& improvement }\end{array}$ & 12. & 7.33 & 1.81 & 12. & 6.90 & 2.04 \\
\hline $\begin{array}{l}\text { Workshops on teaching methods for } \\
\text { targeted groups }\end{array}$ & 13. & 7.31 & 1.80 & 5. & 7.55 & 1.64 \\
\hline Availability of expert teaching consultant & 14. & 7.29 & 1.92 & 11. & 7.12 & 1.85 \\
\hline $\begin{array}{l}\text { Temporary workload reduction for course } \\
\text { improvement/revision }\end{array}$ & 15. & 7.20 & 1.84 & 17. & 6.77 & 1.95 \\
\hline $\begin{array}{l}\text { Regular (non-t\&p) review of faculty } \\
\text { teaching effectiveness }\end{array}$ & 16. & 7.09 & 2.11 & 23. & 6.66 & 2.02 \\
\hline $\begin{array}{l}\text { Funds for faculty to attend } \\
\text { conference/course on teaching }\end{array}$ & 17. & 7.08 & 1.76 & 18. & 6.76 & 1.88 \\
\hline Table continues & $*$ denotes tie & & & \\
\hline
\end{tabular}




\begin{tabular}{|c|c|c|c|c|c|c|}
\hline \multicolumn{7}{|l|}{ Table II (continued) } \\
\hline $\begin{array}{l}\text { Teaching dossier recognized record of } \\
\text { teaching accomplishments }\end{array}$ & 18. & 7.07 & 1.88 & 21. & 6.71 & 2.10 \\
\hline $\begin{array}{l}\text { Mid-term student feedback to instructor } \\
\text { (formative) }\end{array}$ & 19. & 7.04 & 1.96 & 20. & 6.73 & 2.01 \\
\hline $\begin{array}{l}\text { Conference on teaching and learning } \\
\text { held on campus }\end{array}$ & 20. & 7.01 & 1.73 & 14.* & 6.82 & 1.73 \\
\hline $\begin{array}{l}\text { Seminars on understanding student } \\
\text { learning }\end{array}$ & 21. & 6.96 & 1.69 & 16. & 6.78 & 1.65 \\
\hline $\begin{array}{l}\text { Classroom observation by peers for } \\
\text { improvement purposes }\end{array}$ & 22. & 6.94 & 1.78 & 27. & 6.41 & 1.99 \\
\hline Sabbatical leaves for improving teaching & 23. & 6.84 & 2.00 & 24. & 6.60 & 2.17 \\
\hline $\begin{array}{l}\text { Faculty review of academic program to } \\
\text { improve instruction }\end{array}$ & 24. & 6.70 & 1.93 & 14.* & 6.82 & 1.89 \\
\hline $\begin{array}{l}\text { Senior admin. foster institutional pride } \\
\text { which stimulates effective instruction }\end{array}$ & 25. & 6.52 & 2.23 & 25. & 6.45 & 2.13 \\
\hline $\begin{array}{l}\text { Course materials reviewed in university } \\
\text { review procedures (summative) }\end{array}$ & 26. & 6.34 & 2.16 & 29. & 6.20 & 1.97 \\
\hline $\begin{array}{l}\text { Senior admin. emphasizes how research } \\
\text { supports teaching }\end{array}$ & 27. & 6.32 & 2.17 & 19. & 6.74 & 2.14 \\
\hline $\begin{array}{l}\text { Importance of teaching made public by } \\
\text { senior administrators }\end{array}$ & 28. & 6.11 & 2.43 & 13. & 6.84 & 2.58 \\
\hline $\begin{array}{l}\text { Annual report on teaching } \\
\text { accomplishments (summative) }\end{array}$ & 29. & 5.91 & 2.23 & 33.* & 5.71 & 2.23 \\
\hline $\begin{array}{l}\text { Faculty committee with mandate for } \\
\text { improving instruction }\end{array}$ & 30. & 5.85 & 2.12 & 28. & 6.36 & 1.77 \\
\hline $\begin{array}{l}\text { Teaching recognition programs (e.g., } \\
\text { awards) }\end{array}$ & 31. & 5.79 & 2.04 & 31. & 6.00 & 2.18 \\
\hline $\begin{array}{l}\text { Circulation of articles \& newsletters on } \\
\text { teaching }\end{array}$ & 32.* & 5.74 & 1.87 & 30. & 6.10 & 1.65 \\
\hline $\begin{array}{l}\text { Classroom observation by peers/heads } \\
\text { for summative purposes }\end{array}$ & $32 . *$ & 5.74 & 2.04 & 36. & 4.96 & 2.18 \\
\hline $\begin{array}{l}\text { End-of-term student feedback for } \\
\text { summative purposes }\end{array}$ & 34. & 5.25 & 2.35 & 32. & 5.73 & 2.52 \\
\hline Speakers on issues in higher education & 35. & 5.07 & 1.92 & 33.* & 5.71 & 1.83 \\
\hline Readily accessible professional libary & 36. & 4.34 & 2.12 & 35. & 5.14 & 1.99 \\
\hline
\end{tabular}




\begin{tabular}{|c|c|c|c|c|c|c|c|c|}
\hline \multicolumn{9}{|c|}{$\begin{array}{c}\text { TABLE } 3 \\
\text { Categories by Rank }\end{array}$} \\
\hline \multirow[b]{3}{*}{ Category Name } & \multicolumn{4}{|c|}{ United States } & \multicolumn{4}{|c|}{ Canada } \\
\hline & \multicolumn{4}{|c|}{ Category } & \multicolumn{4}{|c|}{ Category } \\
\hline & \begin{tabular}{|c|} 
Categ \\
ory \\
Rank \\
\end{tabular} & $\begin{array}{l}\text { Item } \\
\text { Rank } \\
\end{array}$ & Mean & S.D. & $\begin{array}{c}\text { Categ } \\
\text { ory } \\
\text { Rank } \\
\end{array}$ & \begin{tabular}{|l} 
Item \\
Rank
\end{tabular} & Mean & S.D. \\
\hline "Leadership: Deans \& Heads" & 1 & & 30.85 & 5.95 & 2 & & 28.39 & 6.45 \\
\hline $\begin{array}{l}\text { Deans/heads foster importance } \\
\text { of teaching responsibilities }\end{array}$ & & (2) & & & & (4) & & \\
\hline $\begin{array}{l}\text { Deans/heads promote climate of } \\
\text { trust for classroom observation }\end{array}$ & & (3) & & & & (26) & & \\
\hline $\begin{array}{l}\text { Deans/heads praise \& reward } \\
\text { good teaching }\end{array}$ & & (5) & & & & $(8)^{\star}$ & & \\
\hline $\begin{array}{l}\text { Deans/heads give funds/ } \\
\text { opportunity for classroom } \\
\text { research }\end{array}$ & & (8) & & & & (6) & & \\
\hline $\begin{array}{l}\text { "Employment Policies \& } \\
\text { Practices" }\end{array}$ & 2 & & 29.43 & 6.18 & 1 & & 29.73 & 5.68 \\
\hline $\begin{array}{l}\text { Recognition of teaching in tenure } \\
\text { \& promotion decisions }\end{array}$ & & (1) & & & & (1) & & \\
\hline $\begin{array}{l}\text { Hiring practices require } \\
\text { demonstration of teaching ability }\end{array}$ & & (9) & & & & (2) & & \\
\hline $\begin{array}{l}\text { Regular (non-t\&p) review of } \\
\text { faculty teaching effectiveness }\end{array}$ & & (16) & & & & (23) & & \\
\hline $\begin{array}{l}\text { Teaching dossier recognized } \\
\text { record of teaching } \\
\text { accomplishments }\end{array}$ & & (18) & & & & (21) & & \\
\hline $\begin{array}{l}\text { "Development Opportunities \& } \\
\text { Grants" }\end{array}$ & 3 & & 28.18 & 5.91 & 6 & & 26.53 & 5.86 \\
\hline $\begin{array}{l}\text { Grants to faculty to devise new } \\
\text { approaches to teaching }\end{array}$ & & $(6)^{*}$ & & & & (22) & & \\
\hline $\begin{array}{l}\text { Temporary workload reduction } \\
\text { for course improvement/revision }\end{array}$ & & (15) & & & & $(17)$ & & \\
\hline $\begin{array}{l}\text { Funds for faculty to attend } \\
\text { conference/course on teaching }\end{array}$ & & (17) & & & & (18) & & \\
\hline $\begin{array}{l}\text { Sabbatical leaves for improving } \\
\text { teaching }\end{array}$ & & (23) & & & & (24) & & \\
\hline Table continues & & *den & notes tie & & & & & \\
\hline
\end{tabular}




\begin{tabular}{|c|c|c|c|c|c|c|c|c|}
\hline \multicolumn{9}{|l|}{ Table 3 continued } \\
\hline $\begin{array}{l}\text { "Formative Evaluation of } \\
\text { Instruction" }\end{array}$ & 4 & & 26.81 & 5.63 & 7 & & 26.49 & 5.56 \\
\hline $\begin{array}{l}\text { Consultation on course materials } \\
\text { with faculty peers (formative) }\end{array}$ & & (10) & & & & $(8)^{*}$ & & \\
\hline $\begin{array}{l}\text { Videotaping classroom teaching } \\
\text { for analysis \& improvement }\end{array}$ & & (12) & & & & (12) & & \\
\hline $\begin{array}{l}\text { Mid-term student feedback to } \\
\text { instructor (formative) }\end{array}$ & & (19) & & & & (20) & & \\
\hline $\begin{array}{l}\text { Classroom observation by peers } \\
\text { for improvement purposes }\end{array}$ & & (22) & & & & (27) & & \\
\hline "Educational Events" & 5 & & 26.12 & 5.92 & 4 & & 26.73 & 5.71 \\
\hline $\begin{array}{l}\text { Workshops on teaching methods } \\
\text { for targeted groups }\end{array}$ & & (13) & & & & (5) & & \\
\hline $\begin{array}{l}\text { Conference on teaching and } \\
\text { learning held on campus }\end{array}$ & & (20) & & & & $(14)^{*}$ & & \\
\hline $\begin{array}{l}\text { Seminars on understanding } \\
\text { student learning }\end{array}$ & & (21) & & & & (16) & & \\
\hline $\begin{array}{l}\text { Speakers on issues in higher } \\
\text { education }\end{array}$ & & (35) & & & & $(33)^{*}$ & & \\
\hline $\begin{array}{l}\text { "Leadership: Senior } \\
\text { Administrators" }\end{array}$ & 6 & & 25.85 & 7.32 & 3 & & 27.06 & 7.36 \\
\hline $\begin{array}{l}\text { Senior admin. gives visibility to } \\
\text { teaching improvement activities }\end{array}$ & & (11) & & & & (10) & & \\
\hline $\begin{array}{l}\text { Senior admin. foster Institutional } \\
\text { pride which stimulates effective } \\
\text { instruction }\end{array}$ & & (25) & & & & (25) & & \\
\hline $\begin{array}{l}\text { Senior admin. emphasizes how } \\
\text { research supports teaching }\end{array}$ & & (27) & & & & (19) & & \\
\hline $\begin{array}{l}\text { Importance of teaching made } \\
\text { public by senior administrators }\end{array}$ & & (28) & & & & (13) & & \\
\hline "Structure \& Organizations" & 7 & & 25.57 & 5.92 & 5 & & 26.61 & 5.52 \\
\hline $\begin{array}{l}\text { Center to promote effective } \\
\text { instruction }\end{array}$ & & (4) & & & & (3) & & \\
\hline $\begin{array}{l}\text { Faculty review of academic } \\
\text { program to improve instruction }\end{array}$ & & (24) & & & & $(14)^{*}$ & & \\
\hline $\begin{array}{l}\text { Faculty committee with mandate } \\
\text { for improving instruction }\end{array}$ & & (30) & & & & (28) & & \\
\hline $\begin{array}{l}\text { Teaching recognition programs } \\
\text { (e.g. awards) }\end{array}$ & & (31) & & & & (31) & & \\
\hline Table continues & & *den & hotes tie & & & & & \\
\hline
\end{tabular}




\begin{tabular}{|l|l|l|l|l|l|l|l|l|}
\hline Table 3 continued \\
\hline "Developmental Resources" & 8 & & 24.78 & 4.95 & 8 & & 25.75 & 5.04 \\
\hline $\begin{array}{l}\text { Mentoring programs \& support } \\
\text { for new professors }\end{array}$ & & $(6)^{*}$ & & & & $(7)$ & & \\
\hline $\begin{array}{l}\text { Availability of expert teaching } \\
\text { consultant }\end{array}$ & & $(14)$ & & & & $(11)$ & & \\
\hline $\begin{array}{l}\text { Circulation of articles \& } \\
\text { newsletters on teaching }\end{array}$ & & $(32)^{*}$ & & & & $(30)$ & & \\
\hline $\begin{array}{l}\text { Readily accessible professional } \\
\text { library }\end{array}$ & & $(36)$ & & & & $(35)$ & & \\
\hline $\begin{array}{l}\text { "Summative Evaluation of } \\
\text { Instruction" }\end{array}$ & 9 & & 22.78 & 6.46 & 9 & & 22.47 & 6.53 \\
\hline $\begin{array}{l}\text { Course materials reviewed in } \\
\text { university review process } \\
\text { (summative) }\end{array}$ & & $(26)$ & & & & $(29)$ & & \\
\hline $\begin{array}{l}\text { Annual report on teaching } \\
\text { accomplishments (summative) }\end{array}$ & & $(29)$ & & & & $(33)^{\star}$ & & \\
\hline $\begin{array}{l}\text { Classroom observation by } \\
\text { peers/heads for summative } \\
\text { purposes }\end{array}$ & & $(32)^{\star}$ & & & & $(36)$ & & \\
\hline $\begin{array}{l}\text { End-of-term student feedback for } \\
\text { Summative purposes }\end{array}$ & & $(34)$ & & & & $(32)$ & & \\
\hline
\end{tabular}

\begin{tabular}{|c|c|c|c|c|}
\hline \multicolumn{5}{|c|}{$\begin{array}{l}\text { TABLE } 4 \\
\text { Institutional Structures Devoted to Teaching in the } \\
\text { United States and Canada }\end{array}$} \\
\hline & \multicolumn{2}{|c|}{$\begin{array}{c}\text { United States } \\
165 \text { respondents) }\end{array}$} & \multicolumn{2}{|c|}{$\begin{array}{c}\text { Canada } \\
\text { (51 respondents) }\end{array}$} \\
\hline Structure & $\mathrm{n}^{*}$ & $\%$ & $\mathrm{n}^{*}$ & $\%$ \\
\hline $\begin{array}{l}\text { A center or office devoted } \\
\text { primarily to the improvement } \\
\text { of teaching }\end{array}$ & 98 & 60 & 22 & 43 \\
\hline $\begin{array}{l}\text { A standing faculty } \\
\text { committee on teaching }\end{array}$ & 66 & 40 & 22 & 43 \\
\hline $\begin{array}{l}\text { An ad hoc faculty committee } \\
\text { on teaching }\end{array}$ & 24 & 15 & 17 & 33 \\
\hline Other & 28 & 17 & 9 & 18 \\
\hline \multicolumn{5}{|c|}{$\begin{array}{l}\text { "Some institutions have more than one of these structures. } \\
\text { "Indudes planning bodies for a teaching center or standing committtes, pedagogical resource centers, advisory panels, } \\
\text { teaching awards and grants committees, and structures related to curriculum development and student needs. }\end{array}$} \\
\hline
\end{tabular}




\section{Leadership: Deans and Department Heads}

The data indicates a widespread conviction that deans and department chairpersons have a significant role to play in improving teaching on campus. The aggregate mean of the U.S. responses in this category was 30.85 , the highest of the nine groupings. The Canadian survey yielded an aggregate mean of 28.39 and a ranking of second.

All four items in this category were among the highest ten ratings in both countries, with one exception. ${ }^{3}$ Deans' and chairpersons' recognition of teaching as an important aspect of academic responsibility ranked second in the U.S. and fourth in Canada. Their praising and rewarding of good teaching ranked fifth in the U.S. and eighth in Canada. Department head praise and reward for good teaching was also rated among the most effective teaching improvement practices by Canadian faculty developers in 1988 (Schulz, p. 9). Ranked eighth for the American group and sixth for the Canadian was providing opportunities and funds for classroom research to improve instruction.

The activities described in this category are readily accomplished by deans and department heads and, with one exception, require minimal resources. Providing funding and opportunities for faculty to engage in research on teaching and learning does require a tangible commitment but is an important activity all too often overlooked or rejected as too costly by teaching improvement planners. Our respondents clearly felt that classroom research has a strong potential for improving instruction, but there appears to be little institutional support for this activity. Cochran (1989) reported that chief academic officers at universities and colleges in the United States scored research on teaching the lowest of 25 measures of institutional commitment to teaching and learning. And in Canada, the Report of the Commission of Inquiry on Canadian University Education (Smith,

\footnotetext{
${ }^{3}$ The responses on one item revealed significant differences between the opinions of U.S. respondents and their Canadian counterparts. "Deans and chairs creating a climate of trust which supports classroom observation" ranked third in the U.S. survey and twenty-sixth in the Canadian survey. It should be noted that some ambiguity in the terms used to describe this item (the lack of a clearly defined purpose for the "classroom observation") makes it difficult to draw conclusions from the results. The clear difference between the views of the two responding groups does raise some questions about whether it is due to true respondent variance, instrument error, or some other cause. Further investigation is necessary to resolve these questions.
} 
1991) called for greater support for research into ways to improve teaching and learning.

As academics with administrative responsibility, deans and department chairpersons have considerable influence in the institution through their possession of intellectual authority, their actions as key agents of socialization into the profession, and their role as transmitters of academic culture (Neumann, 1992). Deans and chairpersons can play a pivotal role in improving teaching by creating an environment in which the importance of the teaching function is articulated and supported.

In a study of faculty and their work environment, Blackburn, Lawrence, Bieber, and Trautvetter (1991) found that three measures of faculty perceptions of the environment are strongly related to the effort faculty allocate to teaching: faculty perceptions of institutional expectations regarding teaching effort, their perceptions of other professors' commitment to teaching, and the existence of support services and consensus on curriculum. In each of these areas, deans and department chairpersons can have either a direct or an indirect impact on the perceptions of faculty and the consequent effort they give to teaching and teaching-related activities.

In an evaluation of the Lilly Teaching Fellow Program, Rice and Austin (1990) argue that the role of deans and chairpersons is so significant that, without their active support, "many incentives to encourage good teaching may be fruitless" (p. 39). The four teaching improvement activities in the leadership category represent only a few of the many ways in which deans and department heads can influence attitudes and practices.

\section{Employment Policies and Practices}

The aggregate mean for the second-ranked category "Employment Policies and Practices" was $\mathbf{2 9 . 4 3}$ for the U.S. respondent group, while a mean of 29.73 made this the highest ranked of the nine categories for the Canadian respondent group. In spite of general agreement that employment issues play an important role in teaching improvement, an examination of the individual items in this category 
reveals interesting differences within and between the two national groups.

"Recognition of teaching effectiveness and its evaluation as a significant and integral aspect of all career decisions" achieved the highest ranking in both countries. An earlier survey of Canadian faculty developers ranked a similar item-"university merit and promotion committee carefully scrutinizes teaching" the most effective of 15 practices to improve teaching (Schulz, 1988, p. 9). These results are not surprising: at many institutions there is little incentive for faculty to improve their instructional effectiveness. Diamond (199394) reports that the majority of the 23,000 department chairpersons, deans, and administrators at research universities responding to a recent survey recognize a pressing need "to modify the system to recognize and reward teaching."

A study by the Carnegie Foundation for the Advancement of Teaching (1991) analyzed faculty reports of time spent in class and in preparation for teaching, time spent on research, numbers of publications, class size, and the performance measures used in tenure decisions. The authors concluded that the paths for career advancement vary at different types of institutions in the United States: at researchintensive institutions", "[i]t matters little what is happening in the classroom," while teaching is the primary determinant of success in teaching-intensive institutions (p. 26). But this conclusion may be overstating differences in employment rewards at different types of institutions. Indeed, while the evaluation of teaching appears to play a minor role in tenure decision-making at research-intensive institutions, only one factor relating to teaching performance ("student evaluation of courses taught") was among the "most widely used indicators for tenure decisions" at even teaching-intensive institutions (p. 24).

The relationship between rewards and teaching is further examined in a recent study of faculty activities and incomes. Fairweather (1993) investigated the relationship between salaries and teaching, research, and service activities at 424 colleges and universities in the

\footnotetext{
${ }^{4}$ Institutional type is defined in A Classification of Institutions in Higher Education 1987 ed. Princeton, NJ: The Carnegie Foundation for the Advancement of Teaching.
} 
United States. The results of this study indicate a disturbing pattern: overall, at all types of institutions and for all ranks of the professoriate, research and related activities are better rewarded than instructional activities. Differences among institution types and professorial ranks do exist, but here, too, the findings are troubling. For example, even at liberal arts colleges, where the primary focus is undergraduate education, instructional activities were not significant predictors of pay; indeed, spending more time in class and teaching undergraduates were found to have a negative relationship to compensation (p. 12). The only positive correlation between salaries and teaching at liberal arts colleges was for assistant professors teaching fewer hours to larger classes (p. 11). Fairweather concludes:

These data suggest that efforts to enhance undergraduate education ... have a long way to go to change such a deeply seated reward structure. In the end, to enhance undergraduate education, the faculty and administrative cultures which so strongly support research must learn to see teaching as an important scholarly contribution ... (pp. 11-12)

Our study reveals that $95.5 \%$ of the U.S. respondent group rated "recognition and evaluation of teaching in career decision-making" in the high to moderately-high range. However, there were some differences among respondents from different types of institutions (see Table 5). In particular, $90.6 \%$ of U.S. respondents from "Research I" institutions-the so-called "very high research-intensive institutions" in the Carnegie study-rated the teaching-improvement potential of this item in the "high" range of 8-10, while only $63.8 \%$ of the "low research-intensive institutions" (Comprehensive and Liberal Arts schools) did so. While this result might at first glance appear to be inconsistent with the findings in the Carnegie study, a fair interpretation might be that since measures of teaching performance already play a greater role in tenure decision-making at teaching-intensive institutions, the potential impact of this activity is seen to be higher at research-intensive institutions.

Another item concerning employment policies and practices revealed differences between the two national groups. "Hiring practices require a demonstration of teaching ability" was seen by the Canadians as relatively more important than by the U.S. respondents. This item 
ranked second in the Canadian survey but only ninth in the U.S. survey.

Confidence levels in the remaining two items in this category, which describe policies regarding the evaluation of teaching, were relatively modest for both respondent groups. The regular (in addition to tenure and promotion) review of faculty members' teaching effectiveness achieved a rank of 16 for the U.S. group and 23 for the Canadians. "Keeping a teaching portfolio as the recognized system of recording teaching effectiveness" ranked 18th in the U.S. and 21st in Canada.

\begin{tabular}{|c|c|c|c|c|}
\hline \multicolumn{5}{|c|}{$\begin{array}{l}\text { TABLE } 5 \\
\text { Teaching Improvement Potential of Recognizing } \\
\text { Teaching Effectiveness in Career Decisions } \\
\text { (U.S. Survey) } \\
\text { Respondents were asked to rate their confidence, on a scale of } 1 \text { (least confident) to } 10 \\
\text { (most confident), in recognizing teaching effectiveness in tenure and promotion decisions } \\
\text { as a means of improving instruction. }\end{array}$} \\
\hline \begin{tabular}{|l} 
Institution \\
Type (N) \\
\end{tabular} & $\begin{array}{c}\text { low } \\
(1,2,3)\end{array}$ & $\begin{array}{c}\text { moderately low } \\
(4,5)\end{array}$ & $\begin{array}{c}\text { moderately high } \\
(6,7)\end{array}$ & $\begin{array}{c}\text { high } \\
(8,9,10)\end{array}$ \\
\hline Research I (33) & & 3.1 & 6.3 & 90.6 \\
\hline Research II (12) & & & 33.3 & 66.7 \\
\hline Doctoral I (11) & & & 10.0 & 90.0 \\
\hline Doctoral II (4) & & & & 100.0 \\
\hline $\begin{array}{l}\text { Comprehensive } \\
\text { I (36) }\end{array}$ & 2.9 & 5.7 & 31.4 & 60.0 \\
\hline $\begin{array}{l}\text { Comprehensive } \\
\|(16)\end{array}$ & & & 37.5 & 62.5 \\
\hline \begin{tabular}{|l|} 
Liberal Arts I \\
(11)
\end{tabular} & & & 27.3 & 72.7 \\
\hline Liberal Arts II (8) & & & 28.6 & 71.4 \\
\hline $\begin{array}{l}2 \text { Yr. College } \\
\text { (14) }\end{array}$ & 7.1 & & 28.6 & 64.3 \\
\hline Professional (15) & & 13.3 & 13.3 & 73.3 \\
\hline TOTAL (165) & 1.3 & 3.2 & 22.4 & 73.1 \\
\hline
\end{tabular}


Each of these activities can play an important role in a comprehensive teaching-improvement strategy. Performance reviews may not, in isolation, improve the quality of instruction, but, when coupled with developmental activities, can lead to improvements in the quality of instruction (Trask, 1989; Weimer, 1991).

A policy which encourages the use of the teaching portfolio as a method of documenting teaching performance can have an impact beyond the benefits to the individual faculty member. Because compiling a dossier involves a systematic examination of one's teaching goals, values, performance, and outcomes, faculty are required to engage in the kind of self-reflection and evaluation which leads to behavioral change. In addition, making this type of documentation a part of regular procedures encourages discussion across campus about a variety of educational issues including teaching philosophies and objectives and ways to assess performance and outcomes (O'Neil \& Wright, 1993, pp. 10-16). Such an exchange of ideas helps to raise the profile of postsecondary teaching, to emphasize its importance, and to foster efforts to improve instruction. Support for the use of the teaching portfolio as both a developmental and evaluation tool is growing. After a comprehensive review of the literature, Blackburn and Pitney (1988) recommended the portfolio system for performance appraisal for both administrative and developmental purposes.

\section{Development Opportunities and Grants}

The survey included four items in the category "Development Opportunities and Grants." In the U.S. survey, the ranking of this group of questions was third out of nine categories, while in the Canadian survey this grouping ranked significantly lower-sixth of nine categories. The aggregate means were 28.18 and 26.53 , respectively. The ranks of the individual items ranged from seven to 23 in the U.S. survey and from 17 to 24 in the Canadian.

Grants to faculty to devise new approaches to teaching ranked sixth in the U.S. survey. The practice of institutional grants to enable faculty to develop "new or different approaches to courses or teaching" is well established and widespread: $64 \%$ of the U.S. post-secondary institutions surveyed in 1985 reported providing funds to faculty 
for this purpose (Erickson, 1986). Although a large number of Canadian universities also provide funds for teaching innovation (Wright, 1993), this item ranked only 22nd on the Canadian survey. The difference in ranking between the U.S. and Canadian surveys with respect to this practice is notably high. This gap, for which we have no particular explanation, is surprising since the other items in this category are rated similarly by the two groups. The grants, commonly ranging from $\$ 250$ to $\$ 5,000$, are generally awarded by university committees charged with the assessment of faculty grant proposals. The grants support the development and purchase of innovative teaching materials and facilitate the testing of new teaching strategies (Weimer \& Lenze, 1991; Wright, 1993).

Offering temporary workload reductions for course improvement or revision and funds for faculty to attend conferences or courses on teaching constitute two further strategies to improve teaching. These items ranked 15th and 27th in the U.S. survey, 17th and 28th in the Canadian survey. Frequently, release time from teaching is made possible by the internal funding committees described earlier, but in some instances a separate committee has been established to provide faculty fellowships to develop teaching and learning projects or to enhance teaching skills "when such development or enhancement could not take place in the context of a full teaching load" (Wright, 1993). Erickson (1986) found that temporary workload reductions were available in almost $60 \%$ of the institutions surveyed, though work in the professor's area of research was included as a possible focus along with course revision and development (p. 189).

Travel funds to attend professional conferences were reported available in over $90 \%$ of institutions surveyed by Erickson (1986, p. 189). It is not clear whether these funds were established to specifically support attendance at conferences on university teaching and learning per se. A separate fund offers the advantage of giving priority to conferences on university pedagogy over the discipline-based research meetings which are often funded by other sources.

The provision of sabbatical leaves for the purpose of improving teaching ranked 23rd in the U.S. survey and 24th in the Canadian survey. Four out of every five colleges and universities surveyed by Erickson (1986) offered sabbatical leaves with at least half salary (p. 
189). But we do not know how many institutions award sabbaticals specifically for teaching improvement purposes. A recent study of universities in Atlantic Canada revealed that several institutional policy documents make some reference to teaching improvement as an intended outcome of a sabbatical leave and that one university includes explicit reference to supporting sabbatical projects "directed primarily toward enhancement of teaching" (Brooks, 1993, p. 1).

The fact that the survey question regarding grants to faculty to improve teaching and to innovate ranked seventh in the U.S. survey suggests a relatively high degree of confidence among faculty developers in the potential of these grants. And a review of the effectiveness of this type of grant, as well as the other types mentioned, indicates very high ratings among respondents familiar with the workings of institutional grants programs (Weimer \& Lenze, 1991). Yet we do not know "[w]hether or not grants have any measurable effects on instructional quality" (Weimer \& Lenze, 1991, p. 316). There is a need to investigate the impacts of teaching improvement grants-a popular development strategy which currently involves a considerable expenditure of resources.

\section{Formative Evaluation}

The category "Formative Evaluation" ranked fourth in the U.S. survey (aggregate mean, 26.81) but only seventh in the Canadian survey (26.49). Formative evaluation is conducted primarily for the purpose of feedback and instructional improvement. Students, faculty colleagues, and, at times, 'expert' consultants or faculty/instructional developers are partners in the formative evaluation process.

Consultation regarding course materials (outlines, readings, evaluation procedures, etc.) with faculty peers ranked tenth in the U.S. survey and eighth in the Canadian survey. This type of consultation was practiced in more than half of the colleges and universities surveyed by Erickson (1986, p. 187). Our respondents may rank this item more highly than other formative evaluation techniques because it is straightforward and uncomplicated, undertaken on a cooperative and voluntary basis by peers, and deals with tangible documentary 
(mainly print) evidence of one's approach to teaching, as opposed to a potentially more subjective monitoring of classroom performance.

Videotaping of classroom practice for the analysis and improvement of instruction ranked 12th in both countries while classroom observation by faculty peers to assist in the improvement of instruction ranked 22nd in the United States and 27th in Canada. It is interesting to note that survey respondents have relatively high confidence in videotaping as a tool: it is seen to be potentially more effective than simple classroom observation by peers. Do our respondents have relatively little confidence in peer observation for teaching improvement because of the lack of preparation and training of faculty to allow them to successfully undertake the task? If that is the case, do our respondents believe that protocols for the effective use of videotapes to improve classroom instruction ensure the success of this technique? The authors are of the opinion that both approaches to teaching improvement have considerable potential, but that preparation and training may constitute key factors for their effective use in higher education. The Erickson survey (1986) showed that videotaping of classes for improvement purposes was not as widely available as was classroom observation by peers, especially in private institutions ( $\mathrm{p}$. 187). Weimer and Lenze (1991) report that videotaping for instructional improvement offers "tantalizing possibilities" and that research "seems to indicate a positive impact" of the technique (p. 312).

Mid-term student ratings of instruction as feedback to the instructor ranked 19th in the U.S. and 20th in the Canadian survey. The practice of student ratings is well-established and widespread. Student ratings results (either formative or summative) were available to faculty in over $95 \%$ of colleges and universities according to the Erickson study (1986, p. 187). The availability of trained consultants to help faculty interpret student ratings was much less prevalent ( $\mathrm{p}$. 187). Student ratings programs constitute the most common means of assessing instruction in universities in Canada and the United States today, yet faculty developers view them as having only moderate potential to improve teaching. Perhaps our respondents would rank student ratings more highly if they were more commonly used in conjunction with the services of trained consultants, who would work with faculty to analyze and interpret the ratings and suggest adjust- 
ments to their teaching. Weimer and Lenze (1991) conclude, after a thorough literature review, that consultation regarding student ratings can "make a difference," but that further research is needed to shed more light on this process (p. 312). The authors also found that none of the research on the various consultation techniques designed to improve instruction measured impact in terms of student learning outcomes (p. 312).

\section{Educational Events}

The category of "Educational Events" had an aggregate ranking of fifth (aggregate mean, 26.12) among the nine categories in the U.S. survey. Workshops on teaching methods for targeted groups ranked in the top third (16th) of the 36 items, while on-campus conferences on teaching and learning, as well as seminars on student learning, ranked in the second half among the items (20th and 21st, respectively). Speakers on general issues and trends in higher education ranked near the very bottom of the list (35th). The category ranked sixth in the Canadian survey (26.73). The workshop item ranked fifth; conference and seminars, 14th and 16th; and speakers on issues in higher education, 33rd. Canadian respondents showed more confidence in some types of educational events than did their counterparts in the United States.

Workshops, seminars, and programs are considered the traditional "main staple of the instructional improver's cupboard" (Weimer \& Lenze, 1991, p. 298). Of the various categories of workshops and seminars described by Erickson (1986), those concerned with "various methods or techniques of instruction" were the most common. This type of workshop was offered at over $60 \%$ of the institutions surveyed (p. 187). An inventory of activities sponsored by teaching development offices in Canadian universities also showed workshops to be one of the most common elements of an institutional instructional development program (Schulz, 1988).

Workshops vary as to topic, instructional methods, target population, and length. According to several reviews of workshop/seminar program effectiveness reported in Weimer and Lenze (1991), faculty participants often rate the programs "useful, relevant, and informa- 
tive," especially those which are longer and to which faculty make a significant commitment (p. 304). Experience suggests that workshops should: be planned and publicized thoroughly, address the concerns of a wide range of faculty, be conducted by a resource person who is both knowledgeable and skilled in workshop methodology, engage the participants in active learning, and be evaluated on site by participants. Even then, isolated workshops may have a limited impact. The most successful events relate to a theme pursued in other ways by the instructional development center and/or involve a workshop series to allow a thorough exploration of a topic or an approach to teaching.

At Dalhousie University, the demand for faculty workshops on the teaching portfolio led to discussion of the concept at meetings of the Senate Committee on Instructional Development, to the creation of workshop materials, and, eventually, to the publication of a 100page guide to compiling a teaching portfolio. A series on writing across the curriculum was launched by a major invited speaker, followed by a number of low-key seminars drawing on local faculty as presenters, and culminated in the publication of a compendium of classroom writing assignments and techniques contributed by over 40 faculty members, most of whom participated in the series (Herteis \& Wright, 1992).

Unfortunately, the reputation of workshops relies too heavily on participant feedback and organizer intuition: there is a great need to measure outcomes of this popular component of faculty development programs in terms of observable teaching improvement and increased student learning.

As noted, workshops for targeted groups of faculty are more highly regarded than are the seminars, conferences, and speakers on trends in higher education as suggested by the other items in this category. An international study of faculty development specialists ranked "workshops or programs that explore general trends in higher education" least effective of the six practices included in the survey (Shackelford, Seldin, and Annis, 1993). The Erickson (1986) survey showed that this kind of educational event was, nevertheless, offered by over one-third of the institutions surveyed (p. 186). Specificity, practicality, relevance, involvement, and assessment must be the 
keynotes if educational events are to make a positive impact in the academic community.

\section{Leadership: Senior Administrators}

The category dealing with the leadership of senior administrators ranked sixth (aggregate mean, 25.85) for the U.S. group and third (27.06) for the Canadian. The four items measured are largely concerned with creating an environment which values and supports teaching. They suggest ways administrators can provide, through the use of language and action, "symbolic leadership" in reshaping the institutional culture so that teaching becomes a vital, valued activity (Green, 1990, pp. 48-51). Strong leadership can be highly influential in enhancing the status of teaching and initiating teaching improvement policies and programs:

Deans and academic vice-presidents can cause things to happen-planting ideas, nurturing them, soliciting support from faculty leaders, and pushing ideas through an often tortuous route of dialogue and revision until these ideas are ultimately owned by the affected groups. In other words, in academia, leaders ... can influence the organizational culture to produce change. (Green, 1990, p. 46)

The item in this category with the highest teaching improvement potential according to both U.S. and Canadian respondents (ranking 11 th and 10th, respectively) was "teaching improvement activities given high visibility by the senior administration in order to illustrate their importance." By actively promoting developmental activities, senior administrators send a clear message that the institution both expects effective instruction and will provide faculty with the means to achieve it. The possibilities for action here go beyond lip service. Senior administrators can circulate memos and announcements about instructional development opportunities, make sure they are included on meeting agendas, and urge involvement at a number of levels. They can let nonacademic administrators know that activities related to teaching should be a priority in budgetary considerations and in the provision of support services. They can thus help create an organization which puts its educational mission at the center of its activities. 
The less action-oriented items in this category were seen as having a smaller potential impact on teaching. Canadian respondents expressed moderate confidence in the improvement potential of senior administrators publicly articulating the importance of teaching (rank, 13), but U.S. respondents had relatively little confidence in this item (rank, 28). Because the movement to enhance teaching in higher education is newer and less widespread in Canada, administrators' public pronouncements about the importance of teaching may have a greater impact here than in the United States where such statements have been commonplace for a longer period of time.

Similarly, U.S. respondents had relatively less confidence in the potential impact of senior administrators emphasizing the supportive link between research and teaching (rank, 27) than did the Canadians (rank, 19). The two groups reported similar levels of confidence in senior administrators stimulating effective teaching by fostering pride in the institution (rank, 25 for both).

Clearly, senior administrators have an important role to play in establishing the status of teaching within the institutional environment. The survey results suggest that demonstrations of support may have a greater impact in the early stages of a teaching improvement program, when important attitudinal and behavioral changes have not yet occurred. The sustained and active involvement of senior administrators is an important component of a comprehensive teaching improvement strategy.

\section{Structure and Organization}

This category ranked only seventh (aggregate mean, 25.57) in the U.S. survey and fifth in the Canadian (26.61). The two respondent groups closely agreed on the relative potential of all but one item in this category. Notably, an institutional center to promote teaching and learning received a high level of support from both U.S. and Canadian groups (ranked fourth and third, respectively). There was clear preference for a center over a faculty committee on teaching which ranked in the lowest quartile.

Table 4 details the existing structures reported in the surveys. Canadian post-secondary institutions have proportionately fewer 
teaching centers, but many respondents indicated that more are being planned. These results may be a reflection of the fact that the teaching improvement movement gained momentum earlier in the United States than in Canada. Indications are that these structural differences will disappear over time.

An instructional development center, given adequate resources, has the potential to make a positive impact on the quality of university teaching and learning through the establishment of a sustained, multifaceted program of interventions, such as those described throughout this paper by the authors. Personal observation leads us to postulate that development committees can carry out good work, but that they rely heavily on the availability of volunteer efforts by imaginative and dedicated faculty, and many such committees find it difficult to sustain viable programs and to closely monitor their effectiveness as energies ebb and flow over time. Does the instructional development program organized by a center enjoy greater success on a campus characterized by a rather centralized culture or institutional climate? Are faculty-initiated programs particularly effective in settings where decentralization dominates the campus culture? Do successful centers take into account the campus culture, the campus climate, in determining priorities and program design? These issues should be considered when determining the applicability of our findings to a given milieu.

Only one organizational item revealed a divergence of opinion between the national groups. The involvement of faculty in periodic, comprehensive reviews of academic programs for the purpose of improving instruction (ranked 24th in the United States) was seen to have a relatively modest potential to improve teaching. Canadian respondents judged this strategy more favorably (14th). The culture of the university is such that faculty are, in fact, often involved in academic program review: periodic reviews of all faculty were carried out in almost $75 \%$ of all post-secondary institutions as reported by Erickson (1986). Yet our U.S. respondents accord this widespread practice relatively low priority as a means to improve teaching.

Teaching awards have long been a common means of recognizing outstanding teaching in universities across the United States (Erickson, 1986, p. 189). Yet this item ranks near the bottom of the list for its potential to improve teaching in both the U.S. and Canadian 
surveys. The item was also at the bottom of a survey list in an earlier Canadian study (Schulz, 1988). Why? Perhaps it is due to the very nature of the awards. They are presented to accomplished individuals in academe as a means of publicly recognizing outstanding achievement rather than as a broad-based incentive for teaching improvement.

Many instructional developers promote teaching awards and believe the prizes and associated ceremonies have a role to play in terms of public acknowledgment of teaching excellence by the university. But, at the same time, it is clear that our respondents have no illusions concerning the awards, which do not, in themselves, constitute an effective strategy to improve the teaching of significant numbers of faculty. Note, however, that the authors have not explored the potential of "teaching awards" which are associated specifically with tangible rewards, such as the provision of additional human resources (e.g., teaching assistants) to winners. Nor have we considered innovative alternatives such as group, divisional, or departmental awards to recognize collective teaching program excellence.

The survey results serve to emphasize the importance of establishing and supporting an instructional development center with a mandate to promote instruction and relegate practices - such as academic program reviews, teaching committee work, and awards to roles of secondary importance.

\section{Developmental Resources}

The four survey items grouped under the title of "Developmental Resources" yielded a ranking of eighth in both the U.S. and Canadian surveys (aggregate means 24.78 and 25.75). Two items concerning the availability of human resources to support teaching scored fairly high while the two items concerning the availability of print resources to improve teaching scored very near the bottom of the list of 36 items. (Human resources include mentoring programs and expert consultaton. Print resources include newsletters, articles, and libraries of materials.) Some instructional development centers also invest in multi-media and computer-based materials, but the potential of this type of resource was not, unfortunately, measured in our international survey. 
Mentoring programs, which include such activities as peer consultation and faculty support systems for new professors, ranked sixth in the U.S. survey and seventh in the Canadian survey. Seldin's international survey of faculty developers in 110 colleges and universities ranked the item "master teachers or senior faculty working with new instructors" most effective among six practices designed to improve instruction (Shackelford, et al., 1993, p. 11).

Current interest in mentoring activities for new faculty is widespread. Mentorship programs aim to "help new faculty better understand an institution's goals and objectives and get them started on activities designed to meet these goals" (Weimer \& Lenze, 1991, p. 324). More specifically, new faculty often approach their mentors with questions regarding course planning, classroom problems, teaching styles and techniques, grading, student ratings, and institutional policies with respect to tenure and promotion (Wilfrid Laurier University, 1993a, 1993b). Some authors speculate that the movement to introduce mentorship programs for new faculty stems from discontent over the lack of collegiality in academe (Weimer \& Lenze, 1991). Mentorship programs are designed to share expertise and advice in an open and nonthreatening manner. As such, they typify the spirit of today's faculty development movement-an effort characterized by collegiality, cooperation, and a willingness to communicate ideas on university teaching and learning. Although instructional developers see great potential for mentorship programs in support of new faculty, and participants report high levels of satisfaction, there has been no sustained effort to measure program impact in terms of modified teaching practices and student learning outcomes (Weimer \& Lenze, 1991).

Availability of expert consultation services (on the subject of, for example, course planning, constructing tests, and developing teaching skills) for the improvement of instruction ranked 14th in the U.S. survey. This item was 11 th in the Canadian survey. The surveys did not take into account different approaches to consultation, different models of consultation, and the recent evolution of consultation services. The individual experiences of respondents with specific models of consultation may have had a significant impact on their responses. Erickson's survey (1986) showed that expert consultation on these 
particular matters was particularly prevalent in the public universities and professional schools (p. 187). The availability of expert consultation with a view to improving teaching increased during the last decade, but again in this case the research on effectiveness has focused on client and consultant satisfaction rather than tangible teaching and learning outcomes (Weimer \& Lenze, 1991).

Items regarding the circulation to faculty of newsletters and articles pertinent to teaching improvement the accessibility of a professional library concerned with instructional methodology, teaching skills and the psychology of learning ranked 32nd and 36th. The rankings of these items were also very low on the Canadian survey (30th and 35th). Erickson's survey (1986) showed that about $40 \%$ of all post-secondary institutions surveyed had professional libraries and over $45 \%$ circulated newsletters and articles (p. 189). Apparently these common practices of providing print resources do not, as isolated items, enjoy the confidence of faculty developers (many of whom are, no doubt, newsletter editors) as a preferred means to improve teaching. Perhaps the potential impact of print resources, the usefulness of print resources, can be appreciated only when seen as a part of a comprehensive faculty development program: a professor may benefit from the print resource once motivated by a discussion with a consultant regarding his student ratings or her videotaped teaching sample. At any rate, it is clear that our respondents favor human resources over print resources as a means of improving teaching.

\section{Summative Evaluation of Instruction}

Summative evaluation of instruction refers to assessment of teaching performance for administrative purposes pertaining to personnel decisions such as contract renewal, tenure and promotion, and program planning. For both American and Canadian respondent groups, this category ranked ninth and last with aggregate means of 22.78 and 22.47 , respectively.

It is important to note that while the policies and programs described in this category are not designed to have a direct impact on the quality of teaching, they are inextricably tied to employment policies and practices, a category deemed highly important by respon- 
dents. Teaching effectiveness can be appropriately rewarded only if reliable methods of evaluating teaching are in place. The indirect impact of summative evaluation practices on teaching improvement efforts is, therefore, considerable. The lack of a clear, operative, and dependable framework for carrying out summative evaluation may lead to faculty cynicism and compromise the outcomes of instructional development activities.

The summative evaluation practice seen to have the most potential for improving teaching was the review of course materials as part of university review procedures, although the relative ranking of this item was low for both groups: 26th for the American respondents and 29th for the Canadian respondents. Preparing an annual report of one's teaching accomplishments also received a low ranking: 29th for the U.S. group and 33rd for the Canadian group. However, these practices should not be overlooked when planning a comprehensive teaching improvement program. By establishing review mechanisms to assess educational practices, the institution is demonstrating that it cares about the quality of instruction and that faculty effectiveness in this area will be recognized.

Classroom observation by peers and end-of-term student ratings of instruction, both for summative purposes, were among the lowestranked items for both groups, ranging from 32 to 36 . Again, this does not mean that those concerned with improving teaching should underestimate the potential impact of these activities on teaching improvement efforts. Student ratings of instruction in particular enjoy widespread use in universities and colleges in the United States and Canada (reported by Erickson, 1986, and Donald and Saroyan, 1991, to be around $95 \%$ of institutions in both countries). While research has demonstrated that student ratings have little direct effect on improving instruction when used for summative purposes (Cohen, 1980, 1990), they nonetheless play an important role in the creation of an institutional climate which recognizes and rewards effective teaching. A summative evaluation system built on fairness, reliability, and careful attention to research on the subject provides incentives for faculty to strive for teaching excellence and must surely be a part of efforts to enhance teaching in higher education. 


\section{Conclusion}

Surveys of instructional/faculty development role players in the United States and Canada offer new perspectives on teaching improvement practices in post-secondary institutions in these neighbouring countries. The survey instrument asked respondents to express their degree of confidence in the teaching improvement potential of the individual questionnaire items. The results do not, then, actually measure the tangible outcomes of the various elements of an instructional development program, nor do they directly assess the impact of institutional policy and academic leadership. But the survey results provide considerable insight into the perspectives of key role players in the faculty development enterprise in higher education. As such, it is hoped that interested parties will find this information valuable in providing data to turn to when building, assessing, or modifying an institutional faculty development plan and when searching for ways to support teaching through organizational change and administrative initiatives.

The surveys showed a relatively high degree of consistency in thinking, although there were notable exceptions, between the American respondents and their Canadian counterparts. One way of comparing and contrasting the results of the two surveys is to review the relative rankings of the individual items. Fully eight items were among the top ten rankings for both groups who also named the same six items as the least-preferred.

This convergence of views is most notable in top-ranked items which represent key aspects of institutional policy, academic leadership, and instructional development structure. Improvements in the reward system, having deans and department chairpersons who recognize and foster the importance of the teaching function, and the existence of a teaching center are seen by respondents as the most promising avenues to improved instruction.

Agreement between the groups was not consistent across all items, however. U.S. respondents have much more confidence in grants to faculty for teaching innovation. Why do Canadian faculty developers have relatively little faith in the potential of this type of grant? Could it be that Canadian faculty are less motivated by grant programs, that 
the availability of increased financial resources does not constitute a key factor in improving instruction in the Canadian context? Clearly, the use and outcomes of teaching improvement grants bears further investigation.

Canadians feel that faculty review of programs have a greater potential to improve instruction than do the U.S. respondents. A close, comparative look at structured instructional program review in both countries could reveal the causes of this difference in point of view. The importance of teaching being made public by senior administrators is also seen to have much more potential to improve teaching by the Canadian respondent group. Senior administrators in U.S. universities have been, perhaps, more vocal than their Canadian counterparts in their public declarations in support of the teaching mission in higher education. Have the U.S. faculty developers responding to our survey become disillusioned by public posturing, immune to rhetoric unsupported by resources and action?

The different confidence level expressed by the two respondent groups on some dimensions raise intriguing questions which merit further study. Are there differences in cultures, organizational structures, experiences, or academic traditions in the two countries which would account for the varying perceptions of the respondents? Differences like these and others noted throughout this report reinforce the view that there is no single, correct blueprint for improving teaching and that strategies must be sensitive to local conditions and needs.

This article was structured to reflect the relative rankings of the nine categories defined by the researchers. The most significant findings with respect to the categories are observed at the extremes of their rankings. The two mostly-highly ranked categories for both U.S. and Canadian groups were "Leadership of Deans and Department Chairs" and "Employment Policies and Practices." Both groups also had the least confidence in the teaching improvement potential of "Developmental Resources" and "Summative Evaluation of Instruction."

The fact that "Summative Evaluation" ranked so poorly, coupled with the high ranking for "Employment Policies and Practices," points to a major issue for instructional developers and others concerned with improving university teaching: how can we ensure that institutional policies recognize, support, and reward effective teaching if teaching 
is not carefully scrutinized and evaluated by means of recognized, fair procedures adopted by the academic community? Surely, this question calls for further discussion.

The scope of this article does not allow a report on other important findings useful to teaching improvement planners and practitioners. Future articles will deal with comparisons based on such variables as institution size and structure and respondent role.

Colleges and universities in Canada and the United States continue to search for effective ways to improve the quality of instruction in higher education. As resources become more and more scarce and pressures to produce evidence of positive educational outcomes increase, faculty developers and academic leaders must make judicious choices with respect to the programs and policies they foster in an attempt to improve university teaching and learning. This article lays out a panoply of possibilities based on experience, opinion, and intuition, but there remains much trial and research to be carried out if we are to be confident that our teaching improvement energies are well spent.

\section{References}

Blackburn, R.T., \& Pitney, J.A. (1988). Performance appraisal for faculty: Implications for higher education. Ann Arbor, MI: National Center for Research to Improve Postsecondary Teaching and Learning.

Blackburn, R.T., Lawrence, J.H., Bieber, J.P., \& Trautvetter, L. (1991). Faculty at work: Focus on teaching. Research in Higher Education, 32(4), 363-381.

Brooks, G. (1993). Sabbatical policies in Atlantic universities: Will leave be granted for teaching related projects? (Report to the Association of Atlantic Universities Coordinating Committee on Faculty Development). Halifax, NS: Association of Atlantic Universities.

The Carnegie Foundation for the Advancement of Teaching. (1987). A classification of institutions in higher education. Princeton, NJ: Author.

The Carnegie Foundation for the Advancement of Teaching. (1991, May/June). Researchintensive vs. teaching-intensive institutions. Change, pp. 23-26.

Cochran, L.H. (1989). Administrative commitment to teaching. Cape Girardeau, MO: Step Up.

Cohen, P.A. (1980). Effectiveness of student-rating feedback for improving college instruction: A meta-analysis of findings. Research in Higher Education, 13(4), 321-341. 
Cohen, P.A. (1990). Bringing research into practice. In M. Theall and J. Franklin (Eds.), Student ratings of instruction: Issues for improving practice (pp. 123-132).New Directions for Teaching and Learning: Vol. 43. San Francisco, CA: Jossey-Bass.

Diamond, R. (1993-94). Changing priorities in higher education: Promotion and tenure. Teaching Excellence [bulletin], 5(3).

Donald, J.G., \& Saroyan, A. (1991). Assessing the quality of teaching in Canadian universities. (Report to the Commission of Inquiry on Canadian University Education). Ottawa, ON: Association of Universities and Colleges of Canada.

Erickson, G. (1986). A survey of faculty development practices. To Improve the Academy, 5, $182-197$.

Fairweather, J.S. (1993). Teaching, research, and faculty rewards: A summary of the research findings of the faculty profile project. University Park, PA: National Center on Postsecondary Teaching, Learning, and Assessment.

Green, M.F. (1990). Why good teaching needs active leadership. In P. Seldin and Associates, How administrators can improve teaching: Moving from talk to action in higher education (pp. 45-62). San Francisco, CA: Jossey-Bass.

Herteis, E.M., \& Wright, W.A. (Eds.). (1992). Learning through writing: A compendium of assignments and techniques. Halifax, NS: Dalhousie University, Office of Instructional Development and Technology.

Neumann, R. (1992). Perceptions of the teaching-research nexus: A framework for analysis. Higher Education, 23, 159-171.

O’Neil, M.C., \& Wright, W.A. (1993). Recording teaching accomplishment: A Dalhousie guide to the teaching dossier (4th ed.). Halifax, NS: Dalhousie University, Office of Instructional Development and Technology.

Rice, R.E., \& Austin, A.E. (1990). Organizational impacts on faculty morale and motivation to teach. In P. Seldin and Associates, How administrators can improve teaching: Moving from talk to action in higher education. San Francisco, CA: Jossey-Bass.

Schulz, R.A. (1988, June). Possible successful strategies for teaching development offices (TDO's). Unpublished paper based on a presentation at the Eighth Annual Conference on Teaching and Learning in Higher Education, University of Calgary, Calgary, AB.

Seldin, P. \& Associates. (1990). How administrators can improve teaching: Moving from talk to sction in higher education. San Francisco, CA: Jossey-Bass.

Shackelford, R., Seldin, P., \& Annis, L. (1993, Winter). Lessons learned to improve teaching effectiveness. The Department Chair, 11-13.

Smith, S.L. (Commissioner). (1991). Report of the commission of inquiry on Canadian university education. Ottawa, ON: Association of Universities and Colleges of Canada.

Trask, K.A. (1989). The chairperson and teaching. In A.F. Lucas (Ed.), The department chairperson's role in enhancing college teaching (pp. 99-107). New Directions for Teaching and Learning: Vol. 37. San Francisco, CA: Jossey-Bass.

Weimer, M. (1991). Improving college teaching: Strategies for developing instructional effectiveness. San Francisco, CA: Jossey-Bass. 
Weimer, M., \& Lenze, L.F. (1991). Instructional interventions: A review of the literature on efforts to improve instruction. In J. Smart (Ed.), Higher education: Handbook of theory and research (Vol. 7, pp. 294-333). Bronx, NY: Agathon.

Wilfrid Laurier University. (1993a). Guidelines for mentors. Waterloo, ON: Wilfrid Laurier University, Office of Instructional Development.

Wilfrid Laurier University. (1993b). WLU new faculty mentor program. Waterloo, ON: Wilfrid Laurier University, Office of Instructional Development.

Wright, W.A. (1993). [Teaching Development Funds in Universities in Canada.] Unpublished raw data. Halifax, NS: Dalhousie University, Office of Instructional Development and Technology.

Wright, W.A. (Ed.) (in press). Successful faculty development: Strategies to improve university teaching (working title). Bolton, MA: Anker. 